\title{
Electrochemical Strategies for Titanium Implant Polymeric Coatings: The Why and How
}

\author{
Stefania Cometa ${ }^{1}$, Maria Addolorata Bonifacio ${ }^{1,2}$, Monica Mattioli-Belmonte ${ }^{3}(\mathbb{D}$, \\ Luigia Sabbatini ${ }^{2}$ and Elvira De Giglio ${ }^{2, *}$ \\ 1 Jaber Innovation s.r.l., 00144 Rome, Italy; stefania.cometa@jaber.it (S.C.); maria.bonifacio@uniba.it (M.A.B.) \\ 2 Department of Chemistry, University of Bari “Aldo Moro", 70126 Bari, Italy; luigia.sabbatini@uniba.it \\ 3 Department of Clinical and Molecular Sciences, Università Politecnica delle Marche, 60020 Ancona, Italy; \\ m.mattioli@univpm.it \\ * Correspondence: elvira.degiglio@uniba.it; Tel.: +39-80-544-2021
}

Received: 1 April 2019; Accepted: 18 April 2019; Published: 20 April 2019

\begin{abstract}
Among the several strategies aimed at polymeric coatings deposition on titanium (Ti) and its alloys, metals commonly used in orthopaedic and orthodontic prosthesis, electrochemical approaches have gained growing interest, thanks to their high versatility. In this review, we will present two main electrochemical procedures to obtain stable, low cost and reliable polymeric coatings: electrochemical polymerization and electrophoretic deposition. Distinction should be made between bioinert films-having mainly the purpose of hindering corrosive processes of the underlying metal—and bioactive films—capable of improving biological compatibility, avoiding inflammation or implant-associated infection processes, and so forth. However, very often, these two objectives have been pursued and achieved contemporaneously. Indeed, the ideal coating is a system in which anti-corrosion, anti-infection and osseointegration can be obtained simultaneously. The ultimate goal of all these coatings is the better control of properties and processes occurring at the titanium interface, with a special emphasis on the cell-coating interactions. Finally, advantages and drawbacks of these electrochemical strategies have been highlighted in the concluding remarks.
\end{abstract}

Keywords: electrochemistry; polymer coatings; titanium implants; corrosion protection; biocompatibility

\section{Introduction}

Electrochemical deposition of polymers (ECD) is a relatively new technique for metal modification, even though since ancient times metals have been coated with non-polymeric films by electrochemical processes (e.g., metal plating, anodization and many others).

On the other hand, the synthesis of organic compounds such as polymers has been traditionally accomplished via chemical routes. Alternatively, over the last century, the use of electrochemical methods for polymer synthesis has been investigated at both the laboratory and industrial scale.

ECD has gathered a considerable consensus, since it combines the advantages of an easily controlled and automated technique with the inherent possibility of coating different conducting or semiconducting substrates with polymers having disparate properties [1]. In general, the polymer ECD can be categorized into two separate methods, schematized in Figure 1:

- Electropolymerization or electrosynthesis: polymer is grown directly on the metal electrode surface, starting with an electrolyte solution containing the relevant monomer. The process can be further divided into potentiodynamic, galvanostatic and potentiostatic electropolymerization.

- Electrophoretic deposition: polymer exists in the form of fine powder or solubilized in the electrolyte solution and it is attracted to the metal electrode due to its intrinsic electric charge. 
ELECTROPOLYMERIZATION
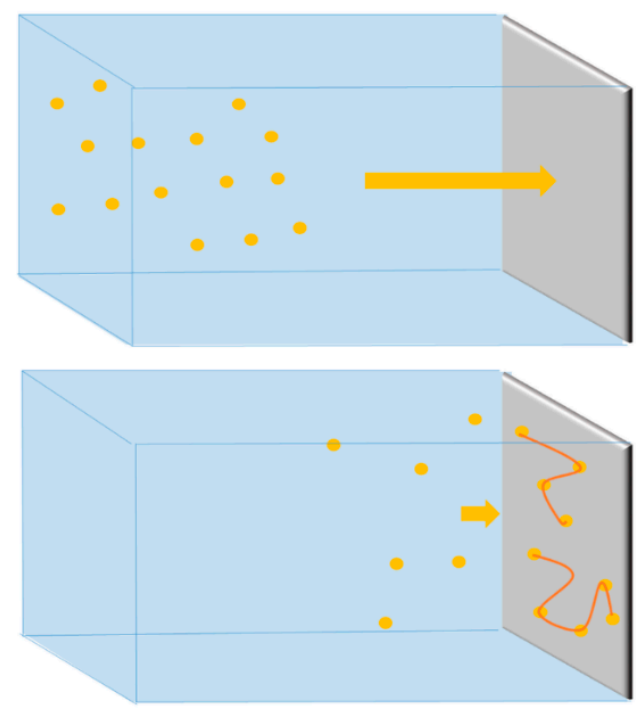

- Monomer
ELECTROPHORETIC DEPOSITION
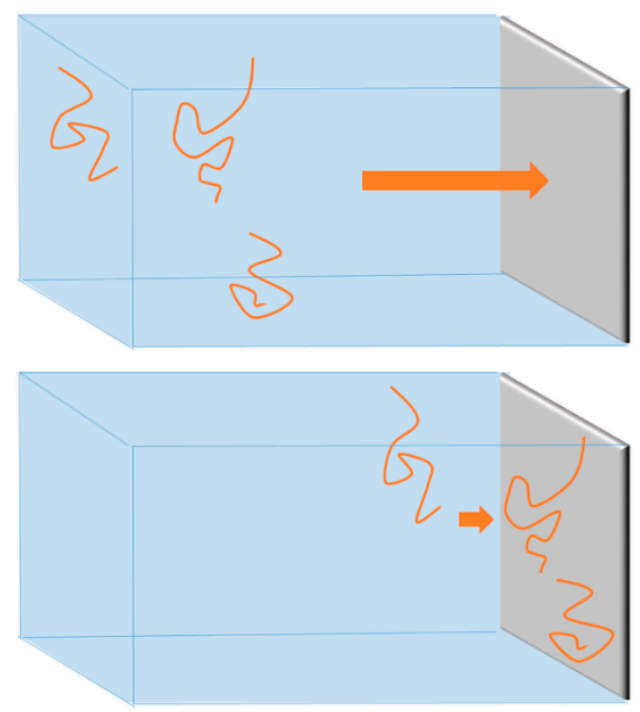

Polymer

Figure 1. Schematic difference between electropolymerization and electrophoretic deposition of polymers to the metal electrode.

The electropolymerization configuration is based on a three-electrode cell (i.e., working, counter and reference electrodes) containing a solution of the monomer (s) and the electrolyte (dopant) in an appropriate solvent. The monomers can be anodically oxidized or cathodically reduced, forming radical anions or cations that react with other monomers, thus forming on the surface of the involved electrode an insoluble polymer layer, which can be conductive, semi conductive or insulating. For insulating polymers, the thicknesses obtainable by electropolymerization are limited to no more than few hundred nanometres, due to the current drop occurring during the film growth. Electropolymerization allows not only to control the film thickness but also to perform in situ characterization of the polymer during its growth with the use of electrochemical and/or spectroscopic methods. Thanks to these properties, the ECD has resulted particularly fascinating in a wide range of application fields, such as corrosion protection in automotive [2,3], electroanalysis [4], electrocatalysis [5], solar cells [6], electronic and microelectronic devices [7], battery technologies, light emitting diodes, electrochromic displays [8] and so forth.

Surely, the greatest impulse to the electropolymerization was given by the development of a sub-class of the chemical sensors, that is, electrochemical sensors and biosensors. The main conducting polymers employed in biosensing are the polyheterocycles, such as polypyrrole (PPy), polythiophene (PT), polyaniline (PANI) and poly(3,4-ethylenedioxythiophene) (PEDOT), developed in the 1980s.

Noteworthy different examples of PPy-based biosensors have been reported in the literature, thanks to its suitability to immobilize enzymes [9]. The interference-free capability of this electrosynthesised polymer was guaranteed by the overoxidation process, which produced a permselective, antifouling membrane able to reject the other typical serum components. PPy films have been electrosynthesized also on mesoporous titanium oxide and resulted able to successfully immobilize glucose oxidase [10].

As far as the electrophoretic deposition process is concerned, it consists of two steps: electrophoresis, that is, the migration of the macromolecules suspended in a solution toward the electrode, attracted by an electrical field and then the formation of a deposit on the electrode surface [11]. Based on the charge of the electrode and of the macromolecules, two electrophoretic deposition processes can be distinguished: cathodic electrophoretic deposition, when the molecules are positively charged and thus attracted to the cathode; anodic electrophoretic deposition, for negatively charged molecules deposited on the anodic surface. 
Both these two main ECD processes allow the irreversible, durable and uniform change of the surface properties of metal substrates. Therefore, ECD finds its natural application in various fields of medicine or biomedical engineering, improving wear resistance or enhancing the affinity of metals with living cells and tissues.

Beyond the classical applications of electrochemical techniques in industrial research areas, the past two decades have seen significant achievements of electrochemistry in biomedicine. Indeed, the development of active materials (e.g., medical devices, modified surfaces), implants, sensors and advanced drug delivery systems has benefited from the knowledge of electrochemical processes naturally occurring in living systems [12]. Moreover, in the last 10 years, electrochemical techniques have been further exploited to create complex patterns of macromolecules, accurately guiding protein deposition on conductive or non-conductive substrates [13]. For instance, the atomic-force-controlled capillary electrophoretic printing (ACCEP) has been developed to control protein positioning with high resolution in time and space, envisioning new opportunities for biomedical research [14]. Furthermore, electrochemistry is also giving a valuable contribution to pharmaceutical applications, especially in the development of remote-control drug delivery systems. In this regard, a noteworthy example was given by Huang et al., who fabricated a flexible antiepileptic-delivery system on PET via electrophoretic deposition. Drug elution was triggered by an external magnetic field, leading to tuneable release kinetics [15]. A similar concept has been exploited to enhance the biocompatibility of metallic cardiovascular devices, mainly made of stainless-steel. Innovative drug-eluting stents (DES) have been developed to in situ release anti-restenotic agents, halving in-stent restenosis phenomena with respect to bare metal devices [16].

Investigations of electrochemical methods is also guiding to very attractive findings in neural repair (e.g., in case of peripheral nerve or spinal cord injuries, glial scar treatment or cochlear functionality restoration). Gomez at al. electrosynthesized PPy layers on gold, in presence of nerve growth factor, observing improved neural cell growth [17]. Furthermore, with a similar approach, Quigley et al. managed to guide Schwann cell migration and axonal growth direction electrodepositing PLA-PLGA aligned fibres on gold substrates [18]. These findings display the potential of electrochemically prepared coatings to modify implant surfaces, aiming at precise cell guidance, with applications in regenerative medicine, especially for electrically-active tissues (i.e., muscular and nervous tissues).

To the best of our knowledge, the longest tradition of implant surface modification with electrochemical techniques is related to orthopaedic and orthodontic devices, with a special focus on titanium and its alloys prosthetic elements (artificial hip joints, artificial knee joints, bone plates, screws for fracture fixation, crowns, bridges, overdentures etc.). Hydroxyapatite layers were already electrodeposited on titanium substrates in 1986 [19]. Since then, a plethora of surface functionalization strategies have been proposed, to endow titanium implants with corrosion resistance, biocompatibility, osseointegration and antimicrobial features. The main phenomena that need to be addressed/avoided when an orthopaedic or orthodontic prosthesis is modified with an ECD coating, are schematized in Figure 2.

A pivotal role of coatings endowed with bioactive, anticorrosion or antimicrobial properties is related to the enhancement of an implant's integration with the surrounding tissues. In this respect, several different in vitro approaches were developed to assess the biocompatibility of electropolymerized or electrodeposited titanium coatings, mainly based on osteoblastic cell lines (i.e., MG63 and Saos-2) or primary cells.

This review article deals with the electrochemical strategies to coat titanium implants with polymeric films, both bioinert and bioactive films. Whereas the former class is mainly focused on titanium-based implants protection against corrosion, the latter involves coatings intended to produce an enhanced biological response, in terms of infection prevention, cell adhesion, new bone matrix deposition and so forth. 


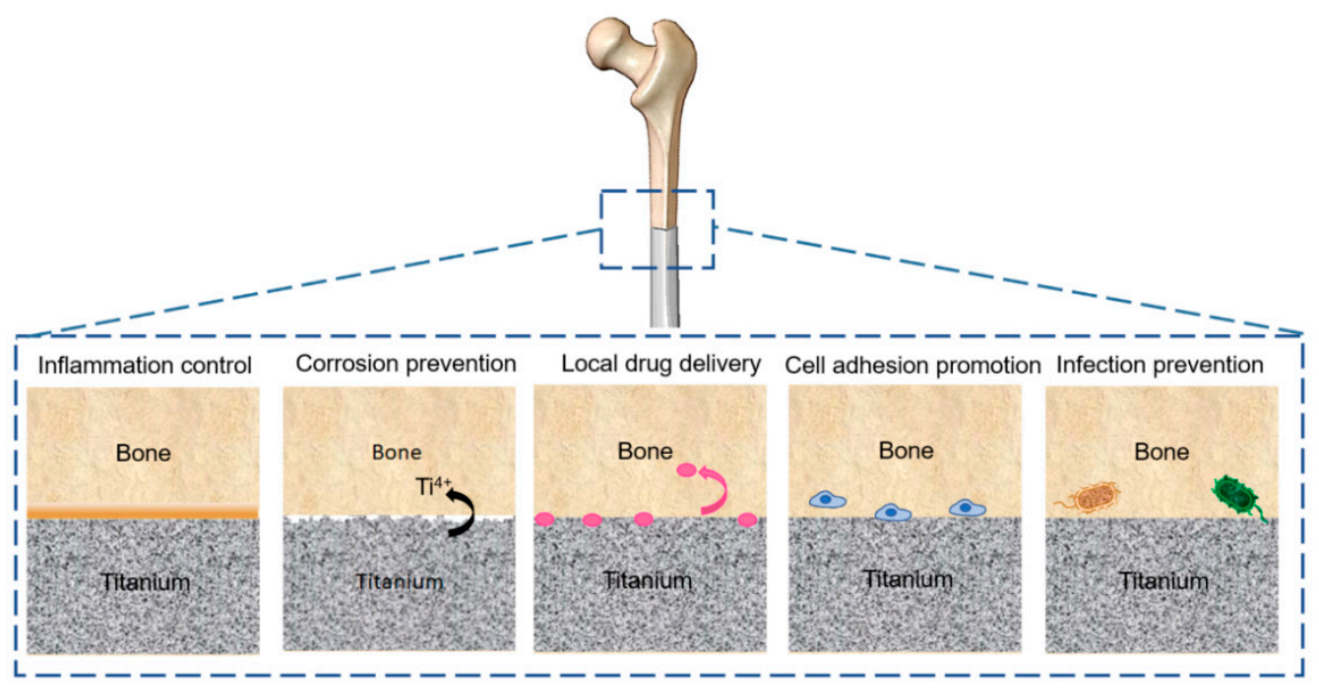

Figure 2. Schematic representation of phenomena occurring at titanium implant-bone interfaces.

In Figure 3, the evolution over time of the number of publications on titanium ECD coatings is reported, suggesting a growing interest toward this research field. On the right of Figure 3, a pie chart shows the distribution of different types of bioactive coatings into three main classes.

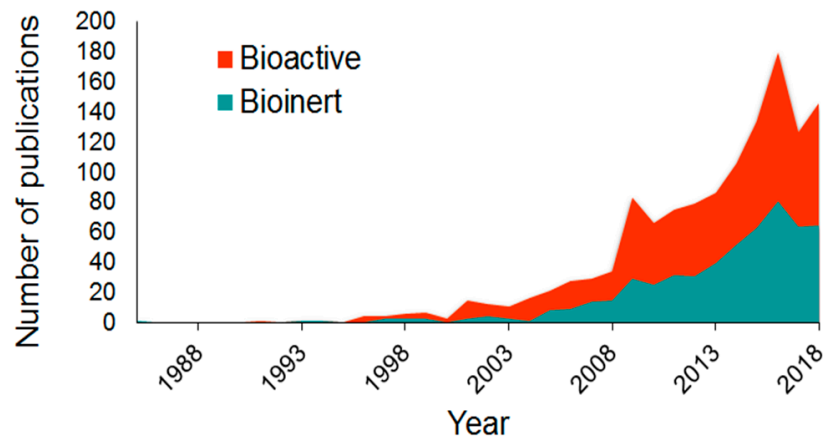

(a)

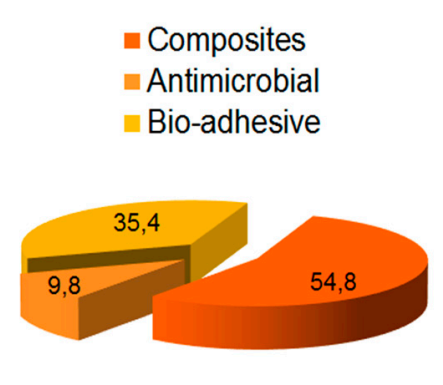

(b)

Figure 3. (a) Timeline of electrochemical deposition (ECD)-based coatings on titanium distinguished in bioinert and bioactive polymer films. (b) Pie chart relevant to the different bioactive coatings. Data source: 2019 Scopus $^{\circledR}$.

The State-of-art in this research field is summarized with the aim to gain insight into the future perspectives of ECD in biomedical fields.

\section{Bio-Inert Systems: Anticorrosion and Barrier Films}

Corrosion of metallic biomaterials is the gradual degradation of the metal surface by an electrochemical attack, which occurs when the metallic implant is placed in the hostile, highly oxygenated, saline, electrolytic environment of the human body. Blood and other constituents of body fluids are rich of different corrosive substances, including water, amino acids or proteins, plasma, mucin in the case of saliva [20], various anions (such as chloride, phosphate and bicarbonate ions), cations (like sodium, potassium, calcium, magnesium, etc.), organic substances of low-molecular-weight species as well as relatively high molecular-weight polymeric components and dissolved oxygen [21,22]. Changes in the $\mathrm{pH}$ values also have a deep impact on metal implant corrosion. Human body $\mathrm{pH}$ value is normally near 7.0; however, this value could drastically decrease due to diseases, infections and other factors and after surgery. Indeed, the $\mathrm{pH}$ value near the implant could lower up to 5.5 or 5.0. Even if metal implants are routinely pre-passivated prior to final packaging using electrochemical 
methods [23], a clinical evidence for the release of metal ions from the implants has been established and this leaching has been ascribed to corrosion processes. Obviously, corrosion attack on metal components of surgical implants is one of the main factor responsible of their short lifetime. This issue is even more severe in the case of prostheses with mobile components. For example, life expectancy of a hip implant is no more than 10 years, mainly due to corrosion phenomena accelerated by the mechanical wear [24].

Commercially pure titanium (CpTi) and its alloys are widely used in orthopaedic and orthodontic applications, also due to their acceptable corrosion resistance [25]. Despite titanium-based implants might not cause any biological adverse reaction, long term stability of these prostheses/implants cannot be totally guaranteed. The lack of surface chemical-physical stability due to corrosive processes could produce many side effects. Indeed, Olmedo and co-workers [26] evidenced the relation between peri-implantitis, a site-specific infectious disease and ion-induced corrosion of the titanium surface.

Resistance to corrosion of titanium implants can be increased by alloying it with aluminium and vanadium or aluminium and niobium (even if also other metals such as molybdenum, zirconium, rhenium, chromium, nickel or manganese have been used). The most frequent use of the Ti-6Al-4V alloy for either orthopaedic or orthodontic implants is linked to an interesting combination of resistance to corrosion, durability, low elasticity module and high osseointegration [27-29]. However, several issues can be related to the side effects of the alloy's components. Detailed studies have shown that they lead to long term ill effects such as peripheral neuropathy, osteomalacia and Alzheimer disease due to the release of aluminium and vanadium ions from the alloy. In addition, vanadium, which is present both in the elemental state and in oxides $\left(\mathrm{V}_{2} \mathrm{O}_{5}\right)$ is highly toxic [30].

In recent years, various researchers have studied different strategies to mitigate titanium-based implants corrosion. In general, this could be attempted by surface modification techniques [31]. Some examples of surface modification processes are physical and chemical vapour deposition [32], laser treatments [33-35], thermal oxidation [36,37] and thermal spraying [38], plasma spray [39,40], ion implantation [41], micro-arc oxidation [42], sandblasting [43,44] and electrochemical treatment [45].

Among these surface modification techniques, the manufacture of multi-materials obtained by deposition of coatings on metals can be a successful way for the mitigation of the metal corrosion process. Polymers, in particular, represent an optimal building block for the achievement of a barrier film on the metal surface.

Different coating strategies can be adopted, such as plasma assisted deposition [46], solvent evaporation [47], sol-gel dip coating [48], dip coating [49] and so forth. As a matter of fact, the application of polymeric protective coatings via electrochemical processes on titanium represents one of the most powerful strategies to obtain a superior adhesion of the polymer layer to the metal substrate with high resistance to mechanical wear.

Although this approach has been widely used in the development of anti-corrosion coatings on various metals (iron, steel, copper, etc.) in different sectors such as naval, aerospace, automotive and so forth [50-52], in the biomaterials field the development of electrochemical polymeric coatings on metals and, in particular, on titanium based implants, for corrosion protection remains a niche study.

In this respect, one of the first studies was carried out by our research group, which achieved the electrosynthesis of a polypyrrole (PPy) coating in aqueous media on both titanium and TiAlV alloy [53]. It is worth noting that, while PPy films are easily synthesized at inert anodes, the electropolymerization at oxidizable metals can occur only under electrochemical conditions that strongly passivate the electrodes without preventing the electropolymerization growth. Indeed, PPy coating is poorly adherent to the oxidizable metals $(\mathrm{Fe}, \mathrm{Zn}, \mathrm{Al}, \mathrm{Ti})$ because of the competition between two simultaneous anodic processes: PPy formation and metal oxidation. Interestingly, in this work it was demonstrated that a thin layer of the native oxide film did not hinder an efficient PPy polymerization on the titanium surface. This polymer is particularly versatile in that it can be either easily functionalized with biologically active molecules, able to stimulate positive interactions with bone tissue or act as an efficient protective barrier. For example, PPy was polymerized starting from the relevant 
monomer solution on anodically polarized NiTi electrode, demonstrating that the polymer improves the corrosion performance at the open circuit potential and at potentials where the bare substrate suffers pitting attack [54]. An improvement in the corrosion resistance property was attempted by the electro-co-deposition of PPy and PEG (composite coating) on Ti-6Al-7Nb alloy. The authors in this paper substantiated the crucial role of PEG in the corrosion tests carried out in Hank's balanced salt solution [55]. The biological response of G292 human OBs was tested onto these PPy/PEG films, showing a good cell viability and proliferation. Furthermore, G292 preserved their morphology within the first $24 \mathrm{~h}$ of culture. Overall, the study suggested that the proposed film offers a microenvironment with an increased bioactivity, improved corrosion resistance and biocompatibility. Finally, another paper proposed the modification of Ti-based implants surfaces through incorporation of torularhodin, a natural compound with antimicrobial effect, by means of a polypyrrole film. The results showed that PPy-torularhodin composite film, besides showing antibacterial activity and no harmful effect on cell viability, acted also as an anticorrosion coating [56]. These observations, as well as other studies with different cytotypes [57], strengthened the role of PPy as a material for different biomedical applications.

Another class of polymers showing interesting barrier properties are the polyacrylates. In 2005, our research group focused on the study of performances of poly(methyl methacrylate) (PMMA) coatings, as such or modified by an annealing process, as barrier films against corrosion of titanium-based orthopaedic implants [58]. In this work, the electrosynthesis of MMA on titanium substrates was performed for the first time by an electro-reductive process from aqueous solutions. This study evidenced that the presence of PMMA coatings produced a decrease in ion release from $\mathrm{Ti}$ alloys. Moreover, the annealing treatment considerably reduced the ion dissolution rate, leading to very efficient protective coatings. As a further improvement of this research, De Giglio et al. carried out the electrosynthesis of poly(acrylic acid) (PAA) films on pure Ti or Ti-6Al-4V sheets [59]. The idea was to obtain a versatile coating for titanium-based orthopaedic implants acting both as an effective anti-corrosion barrier and as a bioactive surface, thanks to the presence of carboxylic groups in PAA that can be functionalized with bioactive molecules. Also in the case of PAA coatings, the annealing procedure resulted in a more compact film able to strongly inhibit the ion release, as demonstrated in simulating tests. Since PAA is a poly-anion, the $\mathrm{pH}$ dependency of the polymer barrier properties was also studied [60], indicating that PAA barrier properties were optimal at a $\mathrm{pH}$ value near the polymer pKa (4.9); this could be ascribed to a good compromise between the number of charged groups and the polymer swelling.

More recently, Meng et al. [61] synthesized a copolymer Poly(2-Hydroxyethyl methacrylateco-2-(Dimethylamino) ethyl methacrylate-co-7-hydroxy-4-methylcoumarin methacrylate) (PHDC))-by free radical polymerization and then self-assembled into colloidal particles and immobilized on the NiTi alloy by a simple one-step electrophoretic deposition. This study demonstrated that the copolymer coatings could significantly decrease the release of nickel ions into the environment. As far as the coating's biological evaluation is concerned, two different cytocompatibility approaches were tested. Indeed, NIH 3T3 fibroblasts were used to assess both the effect of the release of nickel ions through the physical coating barrier and the effect of the direct interaction between the cells and the coating.

Another promising polymer in the biomaterials field is poly(ether ether ketone) (PEEK). The most important properties of PEEK are low density, high mechanical and tribological properties, as well as good chemical and thermal stability and irradiation sterilization resistance. It was also exploited to develop coatings, as such or reinforced with different fibres or particles, by electrodeposition on Ti-13Nb-13Zr [62,63]. Interesting results were obtained in terms of improvement of tribological properties, such as wear resistance, friction coefficient and adhesion of the coatings to the substrate, as well as corrosion resistance. Indeed, scratch tests have been performed on these coatings, revealing no delamination even up to the maximal load of $30 \mathrm{~N}$ (Figure 4a). Cracks at the borders and within the scratch track were visible at high magnifications (Figure $4 \mathrm{~b}$ ). Overall, this analysis evidenced an excellent adhesion of PEEK coatings to Ti-13Nb-13Zr. 

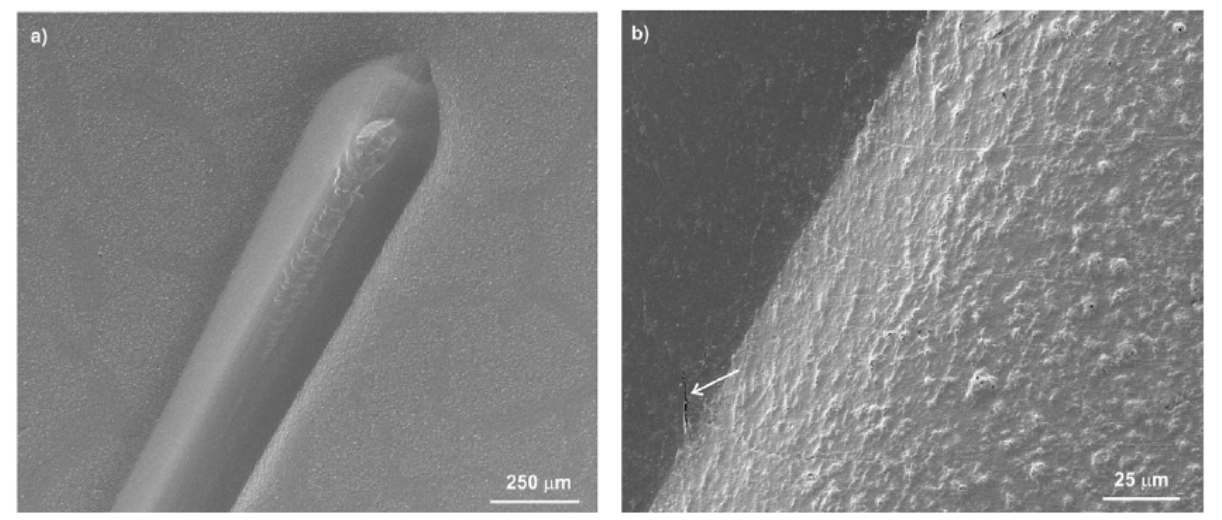

Figure 4. Scanning electron microscope (SEM) images of the poly(ether ether ketone) (PEEK) coating on Ti-13Nb-13Zr after scratch test at a load of $30 \mathrm{~N}(\mathbf{a})$ and $25 \mathrm{~N}$ (b). (Reprinted with permission from [63] 2016 Elsevier, copyright n. 4557620529187).

Composite coatings, based on bioglass/chitosan and sol-gel glass/chitosan, were electrophoretically deposited on a near- $\beta$ Ti-13Nb-13Zr alloy [64]. It was found that both types of coating improve the electrochemical corrosion resistance of the Ti-13Nb-13Zr alloy in Ringer's solution. Furthermore, a good biocompatibility was demonstrated with MG63 osteoblast-like cells.

A recent work discussed the electropolymerization of poly(3,4-ethylenedioxythiophene) (PEDOT) coating on near- $\beta$ Ti-20Nb-13Zr (TNZ), which was pre-treated with three different surface treatments to ameliorate the substrate in terms of morphology, topography and hydrophobicity as well as to facilitate the formation of a compact PEDOT film [65]. The results from electrochemical corrosion studies clearly evidenced that the PEDOT coatings on the surface-treated TNZ substrates improved barrier protection performances in simulated body fluid (SBF).

A further example of protective polymer film electrodeposited on titanium substrates was reported by Bosh et al. [66], which deposited on Ti an anti-corrosion coating based on Halar ${ }^{\circledR}$, an ethylene chlorotrifluoroethylene (ECTFE) thermoplastic polymer, followed by post heat treatment. It was concluded that this polymer could be applied by electrophoresis as protective coating to improve the physical and mechanical properties of the metal substrate and to reduce the stress shielding effect.

Finally, a recent paper reviewed the corrosion resistance of the main types of biocompatible metals, declaring that metals will reasonably continue to be used as biomaterials due to their unmatched mechanical excellence [67]. Therefore, electrochemical polymeric coatings can still provide new solutions for improving the stability of titanium prostheses.

\section{Bioactive Coatings: From Drug-Eluting Systems to Antimicrobial Surfaces}

The previous section dealt with the strategies to protect titanium implants from unwelcome phenomena (e.g., corrosion) due to the interaction between the biomaterial and the surrounding tissues. Besides, several researchers are also focusing on a complementary issue, that is, implant integration through the enhancement of cell adhesion and new matrix deposition.

The interface between a biomaterial and the host microenvironment is the main player in the process that determines implant success or failure. Indeed, several strategies are focusing on titanium surface modification in order to improve cell colonization [68].

An effective method consists in providing titanium with topographical features that stimulate cell adhesion. As an example, Wang and co-workers combined sandblasting, anodic oxidation and acid etching to fabricate micro- and nanoscale structures on titanium implants, studying the effect on cell behaviour [69]. Several other papers [70-73] proposed different techniques (ion implantation, plasma spray, lithography, electric field-aided casting) to engineer metallic surfaces, creating hierarchical patterns to guide cell adhesion. Jeon et al. discussed the impact of pattern shapes (e.g., disordered 
squares, grooves, pillars) on different cell types, providing new perspectives on implant fabrication to finely tune cells' activities [74].

Moreover, beyond the choice of a specific surface pattern, the achievement of a bioactive implant could take advantage from the modification of its surface's physico-chemical features (e.g., wettability, protein adsorption features, degradation rate). Indeed, bare titanium and its alloys, as well as other metallic biomaterials, do not display excellent "biofunctions" intended as the abilities to attract cells and being spontaneously integrated in the surrounding tissues [75]. In this context, the development of bioactive polymeric coatings represents one of the most effective approaches available at reasonable costs. The electrochemical process allows the direct growth of polymeric coatings on titanium, leading to tightly adherent films with adjustable thickness [76]. In this respect, our research group prepared poly(2-hydroxyethyl methacrylate) (PHEMA) coatings on different metallic substrates, using cyclic voltammetry. By simply varying the number of cycles or adding ethylene glycol dimethacrylate (EGDMA) as crosslinker, the authors highlighted the opportunity to tune the polymer thickness, porosity and swelling characteristics, affecting cell adhesion and morphology. The biocompatibility of PHEMA was assessed with fibroblasts, evidencing that hydrogel surfaces had a strong effect on cell adhesion, thus proving useful for both biomedical and diagnostic devices. Indeed, the crosslinked PHEMA-EGDMA coating displayed a smooth and continuous surface, which promoted fibroblasts elongation, while the uncrosslinked PHEMA coating, with its more porous structure, improved cell adhesion and spreading. More recently, Bhattarai et al. electrosynthesized a poly(aniline) coating via cyclic voltammetry, using a titanium-anodized substrate with nanotubular geometry [77]. Their work demonstrated the role of the polymeric coating in enhancing pre-osteoblasts attachment, spreading and osteogenic differentiation. Moreover, Popescu et al. afforded the deposition of a PPy coating through the bioinspired self-polymerization of an adhesive poly(dopamine) layer, which was able to improve the stability and duration of the PPy coating [78].

Beyond the electrosynthesis of polymers starting from their relevant monomers, electrophoretic deposition is an effective alternative, widely used to prepare films based on nature-derived polymers. In this respect, Kamata et al. developed a collagen-electrodeposited coating on titanium, discussing the superior homogeneity of electrochemically assisted deposition as compared to a conventional dipping technique [79]. Moreover, Zhuang et al. recently managed to align chitosan nanofibers on titanium using a magnetically assisted chemical electrodeposition that involved the incorporation of iron oxide nanoparticles (IOPs) and the application of an external magnetic field during ECD. This aligned collagen coating positively guided bone marrow mesenchymal stem cells (BMSCs) growth and elongation, favouring cell differentiation toward an osteogenic phenotype (e.g., expression of $m$ RNA for ALP, COLL I and OCN) [80].

In addition to the already discussed benefits, coating of metallic implants with a polymeric, bioactive film involves the advantage to use it as a versatile platform to load and deliver bioactive molecules (e.g., drugs, growth factors or proteins). Through electrochemical techniques, the bioactive molecules could be entrapped during the coating formation and their release kinetics could be controlled varying the coating's features, as well as the electrochemical parameters. Moreover, since biomolecules are often sensitive to harsh temperatures, extreme $\mathrm{pH}$ conditions and UV exposure, the electrochemical route could preserve them from denaturation or chemical rearrangement.

Following these principles, in 2008 our research group electrosynthesized three acrylate-based hydrogels in presence of a model drug (caffeine) and a model protein (bovine serum albumin), pointing out that their release could be tuned by controlling the nature and/or the amount of the coating's crosslinker [81].

Several classes of bioactive molecules (e.g., anti-inflammatory and anticancer drugs, antimicrobials, growth factors) have been loaded on titanium and its alloys, exploiting polymeric coatings to modulate their release kinetics. As an example, indomethacin, an anti-inflammatory drug, was loaded on titanium, modified with an array of titania nanotubes (TNT) and coated with a thin, biodegradable layer of chitosan and poly(lactide-co-glycolide) [82]. The presence of the polymeric coating enabled to 
extend the drug release up to one month and to adjust it, playing with the film thickness. Furthermore, the model drug ibuprofen was also loaded in an electrochemically deposited chitosan coating on titanium by means of an inorganic carrier (i.e., mesoporous silica nanoparticles) [83] (Figure 5).

This system demonstrated different drug release profiles in response to $\mathrm{pH}$ and electrical stimuli, providing new opportunities to trigger the desired drug release with externally controlled signals. In addition, to address the complex issue of poor vascularization around the implant, other authors managed to develop a VEGF-loaded coating on titanium implants, able to promote both mineralization and in situ angiogenesis, two processes strictly interrelated during osseointegration. MG63 human osteoblast-like cell behaviour was assessed up to 21 days, demonstrating their adhesion, viability and maintenance of osteoblastic phenotype [84,85].

Even if the controlled release of a bioactive molecule is the goal to achieve in several applications, a wide range of surface functionalization techniques is also devoted to the development of stable, bioactive surfaces via grafting of chemical groups (e.g., moieties to be used as organic bridges to improve titanium reactivity, adhesive molecules, anti-thrombogenic drugs, etc.). In this respect, De Giglio's research group focused on the electrochemical coating of titanium with a tightly adherent PPy film, modified with L-cysteine as terminal residue $[53,86]$.
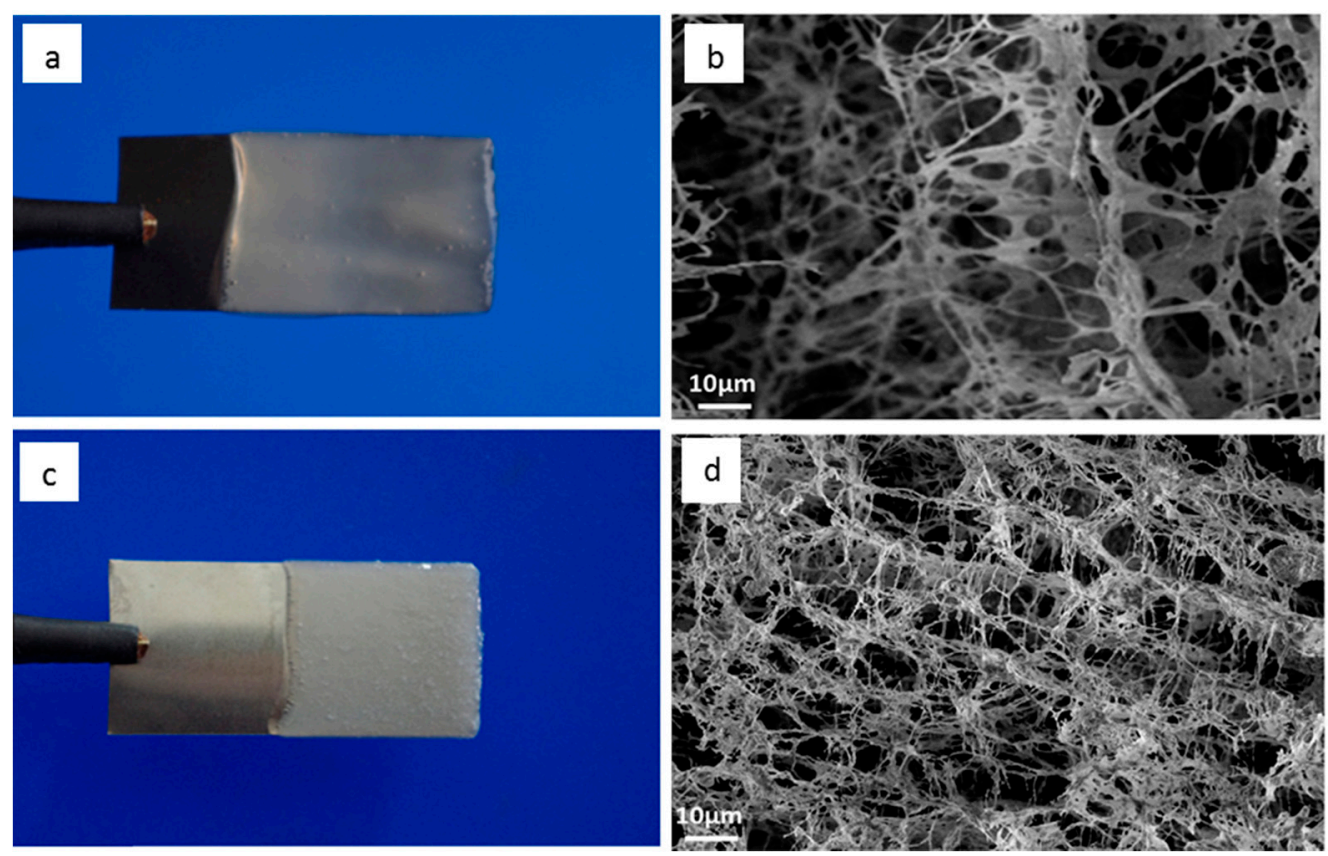

Figure 5. Optical picture (a) and SEM image (b) of electrodeposited chitosan without ibuprofen-mesoporous silica nanoparticles. Optical picture (c) and SEM image (d) of the chitosan coating embedding ibuprofen-mesoporous silica nanoparticles. (Reprinted with permission from [83] 2014 Elsevier, copyright n. 4557620011536).

Furthermore, this single amino acid was exploited to covalently bind a peptide sequence containing the RGD moiety, to enhance osteoblasts attachment on the implant surface [87]. Indeed, the authors observed an adhesion improvement of newborn rat calvaria cells equal to $230 \%$ on the modified coating, correlated to RGD surface density. Other authors grafted the RGD sequence on PEG coatings, exploiting different techniques (plasma polymerization, electrodeposition, silanization). Their aim was to achieve an antifouling system able control osteoblasts adhesion while inhibiting random protein adsorption and biofilm formation. Morphological observation showed that RGD improved cells adhesion, whilst no differences were detected for cells spreading and morphology. Authors concluded that the impaired cell adhesion due to the antifouling feature of the PEG coatings was improved by 
the immobilization of the RGD cell adhesive motive, while maintaining the effect on the bacterial adhesion [88].

Another successful strategy consists in modifying the relevant monomers for electropolymerization, in order to confer further reactivity to the coating. In this regard, a carboxylic acid-substituted PPy (PPy-3-acetic acid) was electrosynthesized on titanium, allowing the subsequent grafting of adhesive sequences [89]. Cell adhesion, which is essential in cell growth, migration and differentiation, as well as $m$ RNA levels of Alkaline Phosphates (ALP), Collagen Type I (COLL I) and osteocalcin (OCN) were studied up to 4 days of cell culture. The viability of osteoblasts (OBs), obtained from mouse bone marrow, was not affected by the developed coating. Moreover, OBs adhered and proliferated on the electrosynthesized PPy-3-acetic film, preserving their osteoblastic phenotype.

Covalent binding techniques are also being investigated to graft anti-thrombogenic molecules on metallic implants, hindering platelets activation. As an example, $\mathrm{Li}$ et al. proposed a fibronectin-heparin coating on titanium, able to accelerate the endothelialization process, improving blood compatibility of metallic implants such as heart valves, stents or ventricular pumps [90]. In addition, Wagner and co-workers explored the opportunity to lower the thromboembolic risk associated with titanium implants used as ventricular assist devices. These authors modified titanium surfaces with poly(2-methacryloyloxyethyl phosphorylcholine) (MPC), a phospholipidic polymer. They demonstrated superior in vitro blood compatibility, opening new perspectives for milder intravenous anticoagulant therapies [91].

All the examples cited so far demonstrate that the combination of polymeric coatings with metallic biomaterials helps overcoming the drawbacks related to bare metals. As far as the bioactivity of a metallic implant is concerned, one of the most successful strategies is based on the development of composite biomaterials, able to mimic natural tissues. In this respect, composite biomaterials are particularly useful for orthopaedic applications, given the intrinsic dual nature of bone, with its organic (mainly collagen) and inorganic (hydroxyapatite) phases tightly intertwined. Several attempts to recreate native bone microenvironment on titanium implants have been reported, consisting in immobilizing the main components of the surrounding tissue on the biomaterial surface [92-94]. As an example, collagen was embedded during PPy electropolymerization, adjusting the applied potential to allow the collagen fibres, positively charged, to be attracted by a titanium electrode. Then, hydroxyapatite was sprayed on the PPy coating leading to a bone-mimicking composite surface [95]. More recently, other authors observed that the use of bioinspired materials (e.g., nacre, bioactive glasses, silk fibroin, etc.) could stimulate implant integration better than the precise reproduction of native bone. Therefore, several research groups studied hydroxyapatite substitutes to trigger an improved osteointegration of metallic implants [64]. Similarly, collagen was replaced by other low-cost nature-derived polymers, such as chitosan. Recently, Zhang et al. reported the successful deposition of calcium phosphate/chitosan/gentamicin films on titanium alloys, enhancing bone regrowth at levels significantly higher than the normal bone growth rates [96]. Moreover, Boccaccini's research group developed a chitosan/bioactive glass composite on titanium alloys, previously treated by grit blasting in order to tune the surface topography, roughness and wettability. The authors discussed the opportunity to change the applied voltage during electrophoretic deposition to modify the coatings' morphology [97]. With the same perspective, Metoki et al. chemisorbed on Ti-6Al-4V several self-assembled monolayers (SAM) with different end-group charge, length of the chains and anchoring groups, observing their impact on the electrodeposition of calcium phosphate $(\mathrm{CaP})$. The morphology of the coating was mainly affected by the end-group type of the SAM, affecting cell colonization, spreading and biomineralization around the implant [98].

The reviewed strategies to promote biomaterials' osseointegration are often combined with tools to prevent implant infections. Indeed, a delicate, dynamic equilibrium between the risk of bacterial colonization and host's cells adhesion is immediately established after implantation, a process which is called "the race for the surface" [99]. Several works have been addressed to investigate if polymeric coating endowed with antimicrobial properties can be tethered to biomaterial surfaces without losing 
functionality as well as maintain compatibility with the surrounding environment. Such strategies allow the administration of the antimicrobial agents with the benefit of providing direct interaction with the site of infection. Different strategies could be pursued, such as antibiotics loading into swellable polymers, release during polymer degradation and/or the use of antibacterial molecules directly as coating components. An example of antimicrobial compounds loaded into a swellable polymer is reported in reference [100].

In this respect, electropolymerized coatings based on PHEMA swelling were designed to deliver antimicrobial drugs. Cell adhesion and viability were evaluated up to $120 \mathrm{~h}$ of culture, considering the burst release of the ciprofloxacin from the proposed system. Both cytoskeletal organization and cell morphology were unaffected by the presence or release of ciprofloxacin as evidenced by immunofluorescence and SEM observations (Figure 6). Moreover, Cometa et al. electrosynthesized a poly(ethylene glycol diacrylate) (PEGDA) coating on titanium, entrapping vancomycin or ceftriaxone onto its surface. The coatings inhibited methicillin-resistant Staphylococcus aureus in vitro, providing a useful tool for in situ prevention of dental or orthopaedic infections [101].
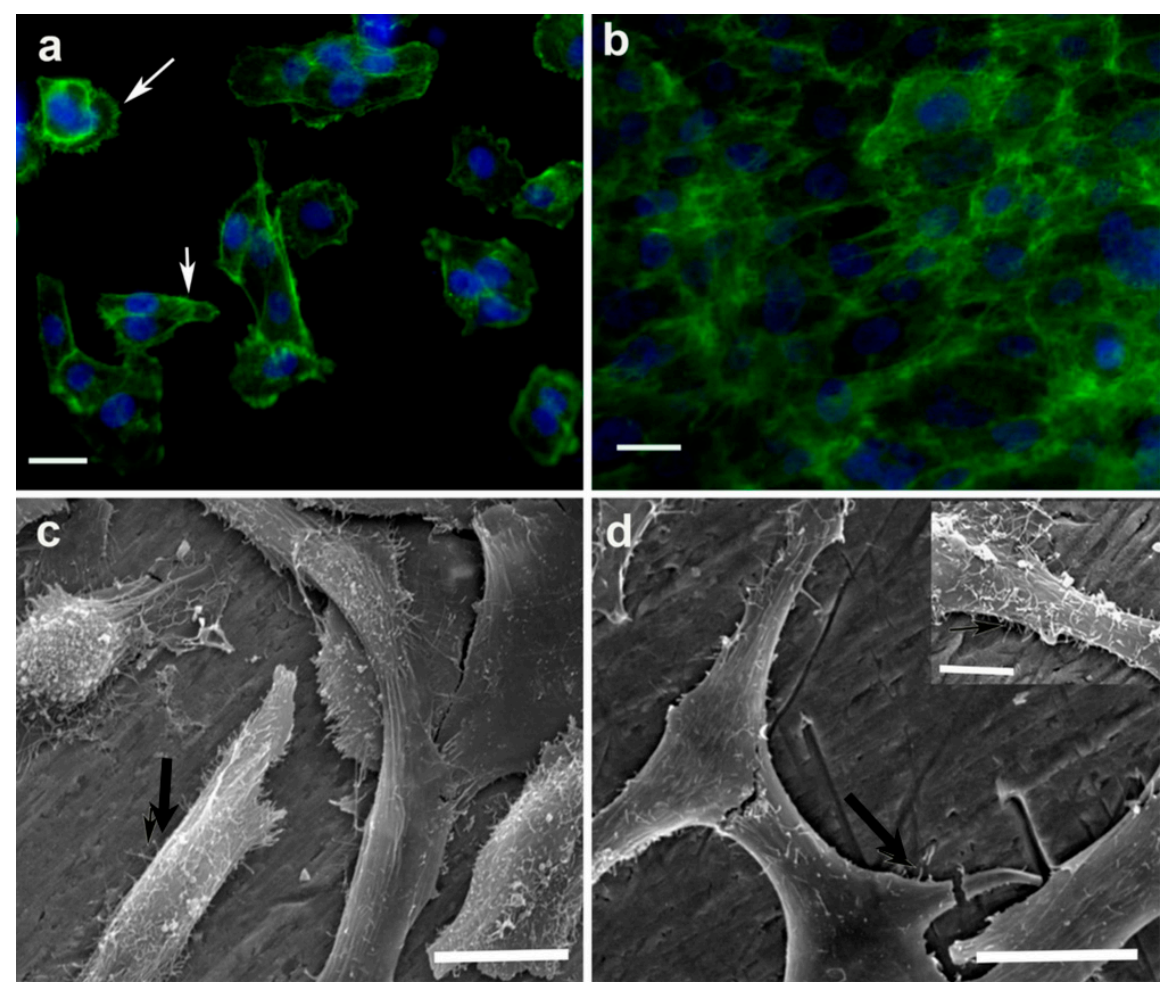

Figure 6. Fluorescence detection of F-actin stress fibres (a,b) and SEM micrographs (c,d) of MG63 cells cultured on ciprofloxacin-loaded PHEMA coatings on titanium at $24 \mathrm{~h}(\mathbf{a}, \mathbf{c})$ and $120 \mathrm{~h}(\mathbf{b}, \mathbf{d})$ of culture. Arrows in (a) indicate local contacts, in (c,d) filopodia and a star-shaped morphology. Main figure scale bar $20 \mu \mathrm{m}$; inset scale bar $5 \mu \mathrm{m}$. (Reprinted in part with permission from [100] 2011 Elsevier, copyright n. 4557620729304).

More recently, Raj et al. developed a titanium alloy coating based on $\mathrm{TiO}_{2}-\mathrm{SiO}_{2}$ mixtures, chitosan-lysine biopolymers and electrodeposited gentamicin sulphate (Figure 7). The antimicrobial experiments against $S$. aureus and E. coli demonstrated that the coating could be useful to eradicate bone infections caused by Gram-negative and Gram-positive bacteria, while repairing bone loss subsequent to osteomyelitis [102].

Beyond conventional antibiotic drugs, antimicrobial peptides (AMP) represent an intriguing alternative to address the concerning issue of drug resistance. In this regard, Hoyos-Nogués et al. prepared a trifunctional coating based on a PEG anti-fouling polymer, embedding both cell adhesive 
molecules and an AMP. The modified titanium surface hindered protein adsorption and S. sanguinis adhesion, while promoting the attachment and spreading of osteoblasts. Data reported are within the $4 \mathrm{~h}$ after seeding and are promising for future application in bone replacing approaches [103].
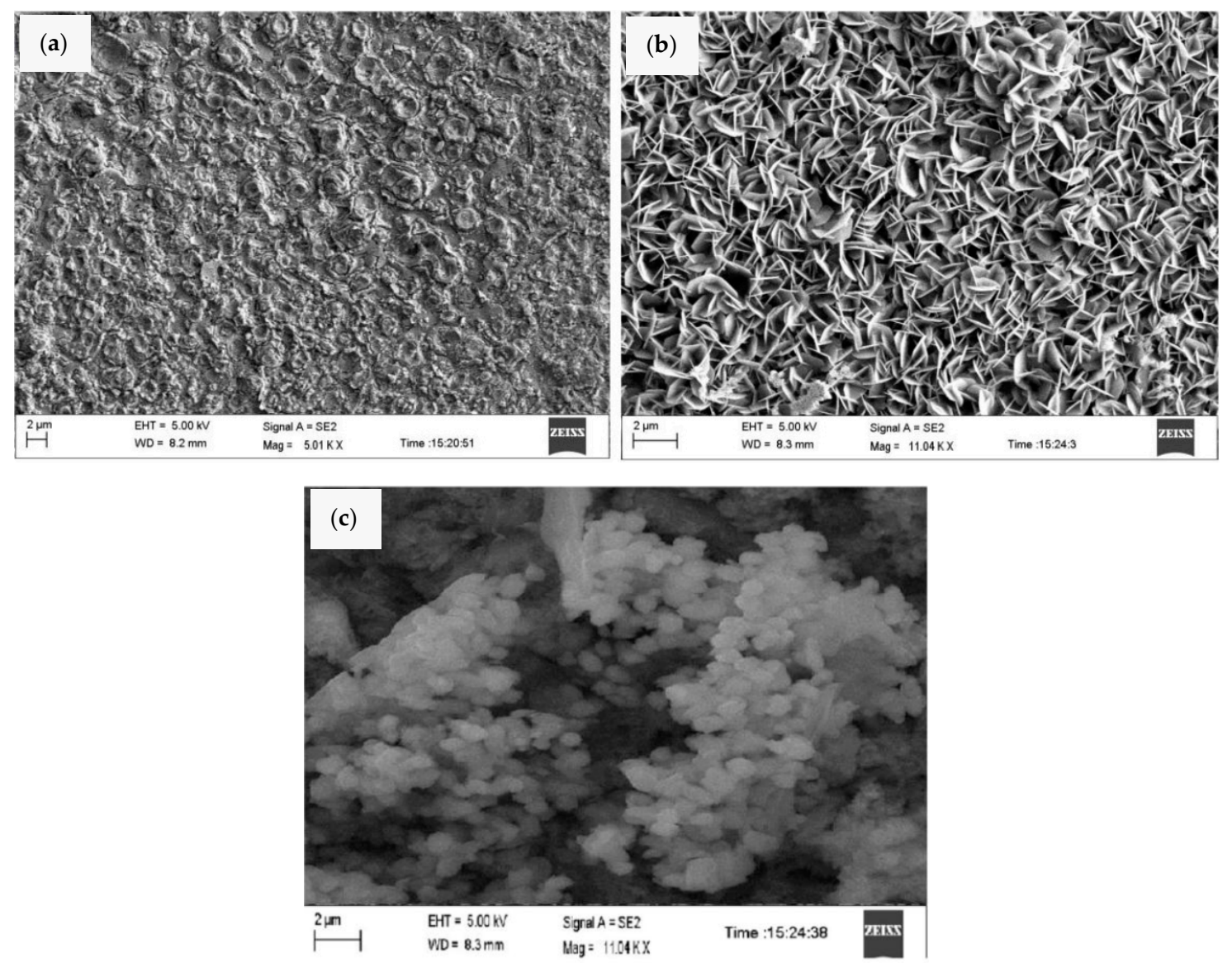

Figure 7. FESEM images of $\mathrm{TiO}_{2}-\mathrm{SiO}_{2}$ coating (a), $\mathrm{TiO}_{2}-\mathrm{SiO}_{2} /$ Chitosan-Lysine coating (b) and hydroxyapatite formation on Drug loaded on $\mathrm{TiO}_{2}-\mathrm{SiO}_{2} /$ Chitosan-Lysine coating (c). (Reprinted with permission from [102] 2018 Elsevier, copyright n. 4557620827469).

Even antimicrobial metals, in the form of ions or nanoparticles, have been extensively studied as antibiotics substitutes, because of their ability to inhibit microbial proliferation and biofilm formation $[104,105]$. Several studies pointed out the effectiveness of silver ions and/or nanoparticles, even if cytocompatibility was not always considered [106]. In 2013, De Giglio et al. electrosynthesized a PEGDA-co-acrylic acid coating, embedding silver nanoparticles obtained by a green procedure. The developed system displayed in vitro antibacterial effectiveness on two $S$. aureus clinical isolates. The presence of AgNPs showed no significant toxic effects on osteoblast-like cells in a week of exposure to the examined coatings [107]. More recently, the same authors prepared composite polymeric coatings based on poly(acrylic acid) and chitosan, modified with silver or gallium ions to merge antibacterial effectiveness with osteointegration enhancement $[108,109]$. Authors evidenced that the viability of MG63 was slightly affected by the gallium-loaded bilayer, whilst no differences were present for cell adhesion, morphology and maintenance of phenotype. Interestingly, changes in coating topography due to the chemical composition represented an instructive pattern for cell arrangement. As far as the silver-loaded bilayer was concerned, cells were affected by the presence of Ag within the polymeric matrix only during the first hours of contact, whilst good cell adhesion, morphology and viability were detected after 7 days of culture. This suggests an acceptable compatibility of the silver-modified coatings with osteoblast-like cells. Overall, the biological observations strengthened the effectiveness 
of these bilayer coatings for a potential application in orthopaedic and/or dental field. An agent-based modelling approach was also adopted to simulate S. aureus interactions with silver-loaded titanium, supporting the choice of the least effective amount of the antibacterial agent [110]. Furthermore, Kim and co-workers electropolymerized poly(dopamine) films, achieving the spontaneous reduction of silver, thus leading to an effective antimicrobial coating [111]. The electrophoretic deposition approach was also exploited by Eraković et al. to attract a silver-doped hydroxyapatite, dispersed in lignin, onto a titanium electrode. Applying constant voltage, it was possible to obtain a system with immediate and continuous release of silver ions, enabling the inhibition of S. aureus growth. Moreover, the coating did not show toxicity against peripheral blood mononuclear cells [112].

The growing research on metal-based antimicrobial coatings suggests that the latter would be potentially coupled with conventional antibiotics to overtake drug resistance, exploiting the effectiveness of metals while limiting their toxicity.

\section{Conclusions and Future Perspectives}

ECD is a fascinating technique for the modification of different metal surfaces and, in particular, it has been successfully applied in biomaterials research, thanks to the possibility of using metals currently employed in both orthopaedic and orthodontic fields as working electrodes.

Not so many techniques are characterized by the main advantages of the ECD, such as low costs, high purity of products, high deposition rates, homogenous covering distribution, capability of combining different monomers to obtain copolymers with a wide range of composition (in the case of electropolymerization), possibility of employing complex geometries of substrate, reduced waste materials, ease of process control and automation.

Moreover, polymer coatings with customized morphology and assemblies can be simply obtained by controlling ECD operating conditions (i.e., initial $\mathrm{pH}$, electrolytic solution composition, current density, deposition time and temperature, typology of electrochemical cell or experimental design etc.).

Finally, ECD can be performed at room temperature from water-based electrolytes, avoiding the use of organic solvents. Hence, ECD can be considered a green chemistry approach to be employed without concerns in biomaterials field, where it is mandatory to avoid the use of potentially toxic substances.

However, there are still some issues to be solved, that represent the current research challenges. Mainly, both electropolymerization and electrodeposition usually produce a fairly dense polymer. Hence, the growth of a passivating polymer film prevents a further polymer deposition (in electrodeposition) or monomer migration (in electropolymerization) on the electrode surface, leading only to very thin coatings. Consequently, other techniques are nowadays required to develop highly porous structures or to obtain thick coatings on titanium.

For all these reasons, when ECD strategies can be exploited, then relatively small areas of conductive substrates could be coated with polymers. Therefore, rather than the scale up of these procedures to coat metal surfaces of large size, the future perspectives of ECD will be related with miniaturisation. Certainly, for the biomedical research, as well as for other technological sectors, it is predictable that the major future trend will be the miniaturisation, rather than the use of macro-devices. In this respect, electrochemical deposition of polymers on metals represents an intriguing strategy, due to the possibility to operate with microelectrodes.

Finally, in the near future, ECD applications are expected to produce tangible improvements in several technological fields, including anti-static coatings, transistors, electromagnetic shielding, organic radical batteries and so on. It is likely that, in the future, the choice of polymeric materials to be employed will fall more often on materials obtained from renewable sources rather than from petrochemical origin. Therefore, with all the advantages discussed in this review, ECD techniques will lead the open challenge to afford "totally green" polymeric coatings on metallic substrates. 
Funding: This research was funded by University of Bari "Aldo Moro".

Conflicts of Interest: The authors declare no conflict of interest.

\section{References}

1. Beck, F. Electrodeposition of polymer coatings. Electrochim. Acta 1988, 33, 839-850. [CrossRef]

2. Mengoli, G.; Musiani, M.M. An overview of phenol electropolymerization for metal protection. J. Electrochem. Soc. 1987, 134, 643C-652C. [CrossRef]

3. Mengoli, G.; Bianco, P.; Daolio, S.; Munari, M.T. Protective coatings by anodic coupling polymerization of o-allylphenol. J. Electrochem. Soc. 1981, 128, 2276-2281. [CrossRef]

4. Kalimuthu, P.; John, S.A. Electropolymerized film of functionalized thiadiazole on glassy carbon electrode for the simultaneous determination of ascorbic acid, dopamine and uric acid. Bioelectrochemistry 2009, 77, 13-18. [CrossRef]

5. Xiao, L.; Wildgoose, G.G.; Compton, R.G. Exploring the origins of the apparent "electrocatalysis" observed at C60 film-modified electrodes. Sens. Actuators B 2009, 138, 524-531. [CrossRef]

6. Granqvist, C.G. Transparent conductors as solar energy materials: A panoramic review. Sol. Energy Mater. Sol. Cells 2007, 91, 1529-1598. [CrossRef]

7. Wang, D.W.; Li, F.; Zhao, J.; Ren, W.; Chen, Z.; Tan, J.; Wu, Z.; Gentle, I.; Lu, G.Q.; Cheng, H.M. Fabrication of graphene/polyaniline composite paper via in situ anodic electropolymerization for high-performance flexible electrode. ACS Nano 2009, 3, 1745-1752. [CrossRef]

8. Reiter, J.; Krejza, O.; Sedlaříková, M. Electrochromic devices employing methacrylate-based polymer electrolytes. Sol. Energy Mater. Sol. Cells 2009, 93, 249-255. [CrossRef]

9. Foulds, N.C.; Lowe, C.R. Enzyme entrapment in electrically conducting polymers. Immobilisation of glucose oxidase in polypyrrole and its application in amperometric glucose sensors. J. Chem. Soc. Faraday Trans. 1 1986, 82, 1259-1264. [CrossRef]

10. Cosnier, S.; Senillou, A.; Grätzel, M.; Comte, P.; Vlachopoulos, N.; Renault, N.J.; Martelet, C. A glucose biosensor based on enzyme entrapment within polypyrrole films electrodeposited on mesoporous titanium dioxide. J. Electroanal. Chem. 1999, 469, 176-181. [CrossRef]

11. Van der Biest, O.O.; Vandeperre, L.J. Electrophoretic deposition of materials. Annu. Rev. Mater. Sci. 1999, 29, 327-352. [CrossRef]

12. Lewenstam, A.; Gorton, L. Electrochemical Processes in Biological Systems; John Wiley \& Sons: Hoboken, NJ, USA, 2015.

13. Ma, R.; Zhitomirsky, I. Electrophoretic deposition of chitosan-albumin and alginate-albumin films. Surf. Eng. 2011, 27, 51-56. [CrossRef]

14. Lovsky, Y.; Lewis, A.; Sukenik, C.; Grushka, E. Atomic-force-controlled capillary electrophoretic nanoprinting of proteins. Anal. Bioanal. Chem. 2010, 396, 133-138. [CrossRef]

15. Huang, W.C.; Hu, S.H.; Liu, K.H.; Chen, S.Y.; Liu, D.M. A flexible drug delivery chip for the magnetically-controlled release of anti-epileptic drugs. J. Control. Release 2009, 139, 221-228. [CrossRef] [PubMed]

16. Levy, Y.; Tal, N.; Tzemach, G.; Weinberger, J.; Domb, A.J.; Mandler, D. Drug-eluting stent with improved durability and controllability properties, obtained via electrocoated adhesive promotion layer. J. Biomed. Mater. Res. Part B 2009, 91, 819-830. [CrossRef]

17. Gomez, N.; Schmidt, C.E. Nerve growth factor-immobilized polypyrrole: Bioactive electrically conducting polymer for enhanced neurite extension. J. Biomed. Mater. Res. Part A 2007, 81, 135-149. [CrossRef]

18. Quigley, A.F.; Bulluss, K.J.; Kyratzis, I.L.B.; Gilmore, K.; Mysore, T.; Schirmer, K.S.U.; Kennedy, E.L.; O'Shea, M.; Truong, Y.B.; Edwards, S.L.; et al. Engineering a multimodal nerve conduit for repair of injured peripheral nerve. J. Neural Eng. 2013, 10, 016008. [CrossRef] [PubMed]

19. Ducheyne, P.; Van Raemdonck, W.; Heughebaert, J.C.; Heughebaert, M. Structural analysis of hydroxyapatite coatings on titanium. Biomaterials 1986, 7, 97-103. [CrossRef]

20. Kubie, L.S.; Shults, G.M. Studies on the relationship of the chemical constituents of blood and cerebrospinal fluid. J. Exp. Med. 1925, 42, 565-591. [CrossRef]

21. Scales, J.T.; Winter, G.D.; Shirley, H.T. Corrosion of orthopaedic implants: Screws, plates and femoral nail-plates. J. Bone Jt. Surg. 1959, 41, 810-820. [CrossRef] 
22. Williams, D.F. Tissue-biomaterial interactions. J. Mater. Sci. 1987, 22, 3421-3445. [CrossRef]

23. ASTM F-86 04 Standard Practice for Surface Preparation and Marking of Metallic Surgical Implants; ASTM International: West Conshohocken, PA, USA, 2004.

24. Hübler, R.; Cozza, A.; Marcondes, T.L.; Souza, R.B.; Fiori, F.F. Wear and corrosion protection of 316-L femoral implants by deposition of thin films. Surf. Coat. Technol. 2001, 142, 1078-1083. [CrossRef]

25. Lemons, J.; Venugopalan, R.; Lucas, L. Corrosion and biodegradation. In Handbook of Biomaterials Evaluation: Scientific, Technical, and Clinical Testing of Implant Materials; von Recum, A.F., Ed.; Taylor \& Francis: New York, NY, USA, 1999; pp. 155-167.

26. Olmedo, D.; Fernández, M.M.; Guglielmotti, M.B.; Cabrini, R.L. Macrophages related to dental implant failure. Implant Dent. 2003, 12, 75-80. [CrossRef]

27. Fleck, C.; Eifler, D. Corrosion, fatigue and corrosion fatigue behaviour of metal implant materials, especially titanium alloys. Int. J. Fatigue 2010, 32, 929-935. [CrossRef]

28. Eisenbarth, E.; Velten, D.; Müller, M.; Thull, R.; Breme, J. Biocompatibility of $\beta$-stabilizing elements of titanium alloys. Biomaterials 2004, 25, 5705-5713. [CrossRef] [PubMed]

29. Niinomi, M.; Boehlert, C.J. Titanium alloys for biomedical applications. In Advances in Metallic Biomaterials; Niinomi, M., Narushima, T., Nakai, M., Eds.; Springer: Berlin, Germany, 2015; pp. 179-213.

30. Walker, P.R.; LeBlanc, J.; Sikorska, M. Effects of aluminum and other cations on the structure of brain and liver chromatin. Biochemistry 1989, 28, 3911-3915. [CrossRef] [PubMed]

31. Liu, X.; Chu, P.K.; Ding, C. Surface modification of titanium, titanium alloys and related materials for biomedical applications. Mater. Sci. Eng. R 2004, 47, 49-121. [CrossRef]

32. Mohan, L.; Anandan, C.; Grips, V.W. Corrosion behavior of titanium alloy Beta-21S coated with diamond like carbon in Hank's solution. Appl. Surf. Sci. 2012, 258, 6331-6340. [CrossRef]

33. Picraux, S.T.; Pope, L.E. Tailored surface modification by ion implantation and laser treatment. Science 1984, 226, 615-622. [CrossRef]

34. Singh, R.; Tiwari, S.K.; Mishra, S.K.; Dahotre, N.B. Electrochemical and mechanical behavior of laser processed Ti-6Al-4V surface in Ringer's physiological solution. J. Mater. Sci. Mater. Med. 2011, 22, 1787. [CrossRef] [PubMed]

35. Yue, T.M.; Yu, J.K.; Mei, Z.; Man, H.C. Excimer laser surface treatment of Ti-6Al-4V alloy for corrosion resistance enhancement. Mater. Lett. 2002, 52, 206-212. [CrossRef]

36. Wang, S.; Liu, Y.; Zhang, C.; Liao, Z.; Liu, W. The improvement of wettability, biotribological behavior and corrosion resistance of titanium alloy pretreated by thermal oxidation. Tribol. Int. 2014, 79, 174-182. [CrossRef]

37. Richard, C.; Kowandy, C.; Landoulsi, J.; Geetha, M.; Ramasawmy, H. Corrosion and wear behavior of thermally sprayed nano ceramic coatings on commercially pure titanium and Ti-13Nb-13Zr substrates. Int. J. Refract. Met. Hard Mater 2010, 28, 115-123. [CrossRef]

38. Arslan, E.; Totik, Y.; Demirci, E.; Alsaran, A. Influence of surface roughness on corrosion and tribological behavior of CP-Ti after thermal oxidation treatment. J. Mater. Eng. Perform. 2010, 19, 428-433. [CrossRef]

39. Zhou, H.; Li, F.; He, B.; Wang, J. Air plasma sprayed thermal barrier coatings on titanium alloy substrates. Surf. Coat. Technol. 2007, 201, 7360-7367. [CrossRef]

40. Cassar, G.; Wilson, J.A.B.; Banfield, S.; Housden, J.; Matthews, A.; Leyland, A. A study of the reciprocating-sliding wear performance of plasma surface treated titanium alloy. Wear 2010, 269, 60-70. [CrossRef]

41. Liu, Y.Z.; Zu, X.T.; Wang, L.; Qiu, S.Y. Role of aluminum ion implantation on microstructure, microhardness and corrosion properties of titanium alloy. Vacuum 2008, 83, 444-447. [CrossRef]

42. Wang, Y.M.; Guo, L.X.; Ouyang, J.H.; Zhou, Y.; Jia, D.C. Interface adhesion properties of functional coatings on titanium alloy formed by microarc oxidation method. Appl. Surf. Sci. 2009, 255, 6875-6880. [CrossRef]

43. Jiang, X.P.; Wang, X.Y.; Li, J.X.; Li, D.Y.; Man, C.S.; Shepard, M.J.; Zhai, T. Enhancement of fatigue and corrosion properties of pure Ti by sandblasting. Mater. Sci. Eng. A 2006, 429, 30-35. [CrossRef]

44. Guilherme, A.S.; Henriques, G.E.P.; Zavanelli, R.A.; Mesquita, M.F. Surface roughness and fatigue performance of commercially pure titanium and Ti-6Al-4V alloy after different polishing protocols. J. Prosthet. Dent. 2005, 93, 378-385. [CrossRef] [PubMed]

45. Arenas, M.A.; Tate, T.J.; Conde, A.; De Damborenea, J. Corrosion behaviour of nitrogen implanted titanium in simulated body fluid. Br. Corros. J. 2000, 35, 232-236. [CrossRef] 
46. Zhou, L.; Lv, G.H.; Ji, C.; Yang, S.Z. Application of plasma polymerized siloxane films for the corrosion protection of titanium alloy. Thin Solid Films 2012, 520, 2505-2509. [CrossRef]

47. Stanfield, J.R.; Bamberg, S. Durability evaluation of biopolymer coating on titanium alloy substrate. J. Mech. Behav. Biomed. Mater. 2014, 35, 9-17. [CrossRef] [PubMed]

48. Catauro, M.; Bollino, F.; Giovanardi, R.; Veronesi, P. Modification of Ti6Al4V implant surfaces by biocompatible $\mathrm{TiO}_{2} / \mathrm{PCL}$ hybrid layers prepared via sol-gel dip coating: Structural characterization, mechanical and corrosion behavior. Mater. Sci. Eng. C 2017, 74, 501-507. [CrossRef] [PubMed]

49. Szaraniec, B.; Pielichowska, K.; Pac, E.; Menaszek, E. Multifunctional polymer coatings for titanium implants. Mater. Sci. Eng. C 2018, 93, 950-957. [CrossRef] [PubMed]

50. DeBerry, D.W. Modification of the electrochemical and corrosion behavior of stainless steels with an electroactive coating. J. Electrochem. Soc. 1985, 132, 1022-1026. [CrossRef]

51. Mengoli, G.; Munari, M.T.; Bianco, P.; Musiani, M.M. Anodic synthesis of polyaniline coatings onto Fe sheets. J. Appl. Polym. Sci. 1981, 26, 4247-4257. [CrossRef]

52. Cram, S.L.; Spinks, G.M.; Wallace, G.G.; Brown, H.R. Mechanism of electropolymerisation of methyl methacrylate and glycidyl acrylate on stainless steel. Electrochim. Acta 2002, 47, 1935-1948. [CrossRef]

53. De Giglio, E.; Guascito, M.R.; Sabbatini, L.; Zambonin, G. Electropolymerization of pyrrole on titanium substrates for the future development of new biocompatible surfaces. Biomaterials 2001, 22, 2609-2616. [CrossRef]

54. Flamini, D.O.; Saidman, S.B. Electrodeposition of polypyrrole onto NiTi and the corrosion behaviour of the coated alloy. Corros. Sci. 2010, 52, 229-234. [CrossRef]

55. Mîndroiu, M.; Pirvu, C.; Cimpean, A.; Demetrescu, I. Corrosion and biocompatibility of PPy/PEG coating electrodeposited on Ti6Al7Nb alloy. Mater. Corros. 2013, 64, 926-931. [CrossRef]

56. Ungureanu, C.; Popescu, S.; Purcel, G.; Tofan, V.; Popescu, M.; Sălăgeanu, A.; Pîrvu, C. Improved antibacterial behavior of titanium surface with torularhodin-polypyrrole film. Mater. Sci. Eng. C 2014, 42, 726-733. [CrossRef] [PubMed]

57. Mattioli-Belmonte, M.; Gabbanelli, F.; Marcaccio, M.; Giantomassi, F.; Tarsi, R.; Natali, D.; Paolucci, F.; Biagini, G. Bio-characterisation of tosylate-doped polypyrrole films for biomedical applications. Mater. Sci. Eng. C 2005, 25, 43-49. [CrossRef]

58. De Giglio, E.; Cometa, S.; Sabbatini, L.; Zambonin, P.G.; Spoto, G. Electrosynthesis and analytical characterization of PMMA coatings on titanium substrates as barriers against ion release. Anal. Bioanal. Chem. 2005, 381, 626-633. [CrossRef] [PubMed]

59. De Giglio, E.; Cometa, S.; Cioffi, N.; Torsi, L.; Sabbatini, L. Analytical investigations of poly (acrylic acid) coatings electrodeposited on titanium-based implants: a versatile approach to biocompatibility enhancement. Anal. Bioanal. Chem. 2007, 389, 2055-2063. [CrossRef]

60. De Giglio, E.; Cafagna, D.; Ricci, M.A.; Sabbatini, L.; Cometa, S.; Ferretti, C.; Mattioli-Belmonte, M. Biocompatibility of poly (acrylic acid) thin coatings electro-synthesized onto TiAlV-based implants. J. Bioact. Compat. Polym. 2010, 25, 374-391. [CrossRef]

61. Meng, L.; Li, Y.; Pan, K.; Zhu, Y.; Wei, W.; Li, X.; Liu, X. Colloidal particle based electrodeposition coatings on NiTi alloy: Reduced releasing of nickel ions and improved biocompatibility. Mater. Lett. 2018, 230, $228-231$. [CrossRef]

62. Moskalewicz, T.; Zych, A.; ukaszczyk, A.; Cholewa-Kowalska, K.; Kruk, A.; Dubiel, B.; Radziszewska, A.; Berent, K.; Gajewska, M. Electrophoretic deposition, microstructure and corrosion resistance of porous sol-gel glass/polyetheretherketone coatings on the Ti-13Nb-13Zr alloy. Metall. Mater. Trans. A 2017, 48, 2660-2673. [CrossRef]

63. Sak, A.; Moskalewicz, T.; Zimowski, S.; Cieniek, .; Dubiel, B.; Radziszewska, A.; Kot, M.; ukaszczyk, A. Influence of polyetheretherketone coatings on the Ti-13Nb-13Zr titanium alloy's bio-tribological properties and corrosion resistance. Mater. Sci. Eng. C 2016, 63, 52-61. [CrossRef]

64. Jugowiec, D.; ukaszczyk, A.; Cieniek, .; Kot, M.; Reczyńska, K.; Cholewa-Kowalska, K.; Pamuła, E.; Moskalewicz, T. Electrophoretic deposition and characterization of composite chitosan-based coatings incorporating bioglass and sol-gel glass particles on the Ti-13Nb-13Zr alloy. Surf. Coat. Technol. 2017, 319, 33-46. [CrossRef] 
65. Kumar, A.M.; Hussein, M.A.; Adesina, A.Y.; Ramakrishna, S.; Al-Aqeeli, N. Influence of surface treatment on PEDOT coatings: Surface and electrochemical corrosion aspects of newly developed Ti alloy. RSC Adv. 2018, 8, 19181-19195. [CrossRef]

66. Bosh, N.; Deggelmann, L.; Blattert, C.; Mozaffari, H.; Müller, C. Synthesis and characterization of Halarßpolymer coating deposited on titanium substrate by electrophoretic deposition process. Surf. Coat. Technol. 2018, 347, 369-378. [CrossRef]

67. Manam, N.S.; Harun, W.S.W.; Shri, D.N.A.; Ghani, S.A.C.; Kurniawan, T.; Ismail, M.H.; Ibrahim, M.H.I. Study of corrosion in biocompatible metals for implants: A review. J. Alloy. Compd. 2017, 701, 698-715. [CrossRef]

68. Ortiz-Hernandez, M.; Rappe, K.; Molmeneu, M.; Mas-Moruno, C.; Guillem-Marti, J.; Punset, M.; Caparros, C.; Calero, J.; Franch, J.; Fernandez-Fairen, M.; et al. Two different strategies to enhance osseointegration in porous titanium: Inorganic thermo-chemical treatment versus organic coating by peptide adsorption. Int. J. Mol. Sci. 2018, 19, 2574. [CrossRef] [PubMed]

69. Ren, B.; Wan, Y.; Wang, G.; Liu, Z.; Huang, Y.; Wang, H. Morphologically modified surface with hierarchical micro-/nano-structures for enhanced bioactivity of titanium implants. J. Mater. Sci. 2018, 53, 12679-12691. [CrossRef]

70. Rautray, T.R.; Narayanan, R.; Kwon, T.Y.; Kim, K.H. Surface modification of titanium and titanium alloys by ion implantation. J. Biomed. Mater. Res. Part B 2010, 93, 581-591. [CrossRef]

71. Zhao, X.; Peng, C.; You, J. Plasma-sprayed $\mathrm{ZnO} / \mathrm{TiO}_{2}$ coatings with enhanced biological performance. J. Therm. Spray Technol. 2017, 26, 1301-1307. [CrossRef]

72. Peng, L.; Zhou, S.; Yang, B.; Bao, M.; Chen, G.; Zhang, X. Chemically modified surface having a dual-structured hierarchical topography for controlled cell growth. ACS Appl. Mater. Interfaces 2017, 9, 24339-24347. [CrossRef]

73. Liang, J.; Song, R.; Huang, Q.; Yang, Y.; Lin, L.; Zhang, Y.; Jiang, P.; Duan, H.; Dong, X.; Lin, C. Electrochemical construction of a bio-inspired micro/nano-textured structure with cell-sized microhole arrays on biomedical titanium to enhance bioactivity. Electrochim. Acta 2015, 174, 1149-1159. [CrossRef]

74. Jeon, H.; Simon, C.G., Jr.; Kim, G. A mini-review: Cell response to microscale, nanoscale and hierarchical patterning of surface structure. J. Biomed. Mater. Res. Part B 2014, 102, 1580-1594. [CrossRef] [PubMed]

75. Hanawa, T. Biofunctionalization of titanium for dental implant. Jpn. Dent. Sci. Rev. 2010, 46, 93-101. [CrossRef]

76. De Giglio, E.; Cafagna, D.; Giangregorio, M.M.; Domingos, M.; Mattioli-Belmonte, M.; Cometa, S. PHEMA-based thin hydrogel films for biomedical applications. J. Bioact. Compat. Polym. 2011, 26, 420-434. [CrossRef]

77. Bhattarai, D.P.; Shrestha, S.; Shrestha, B.K.; Park, C.H.; Kim, C.S. A controlled surface geometry of polyaniline doped titania nanotubes biointerface for accelerating MC3T3-E1 cells growth in bone tissue engineering. Biochem. Eng. J. 2018, 350, 57-68. [CrossRef]

78. Popescu, S.; Ungureanu, C.; Albu, A.M.; Pirvu, C. Poly(dopamine) assisted deposition of adherent PPy film on Ti substrate. Prog. Org. Coat. 2014, 77, 1890-1900. [CrossRef]

79. Kamata, H.; Suzuki, S.; Tanaka, Y.; Tsutsumi, Y.; Doi, H.; Nomura, N.; Hanawa, T.; Moriyama, K. Effects of $\mathrm{pH}$, potential and deposition time on the durability of collagen electrodeposited to titanium. Mater. Trans. 2011, 52, 81-89. [CrossRef]

80. Zhuang, J.; Lin, S.; Dong, L.; Cheng, K.; Weng, W. Magnetically assisted electrodeposition of aligned collagen coatings. ACS Biomater. Sci. Eng. 2018, 4, 1528-1535. [CrossRef]

81. De Giglio, E.; Cometa, S.; Satriano, C.; Sabbatini, L.; Zambonin, P.G. Electrosynthesis of hydrogel films on metal substratesfor the development of coatings with tunable drug delivery performances. J. Biomed. Mater. Res. Part A 2008, 15, 1048-1057.

82. Gulati, K.; Ramakrishnan, S.; Aw, M.S.; Atkins, G.J.; Findlay, D.M.; Losic, D. Biocompatible polymer coating of titania nanotube arrays for improved drug elution and osteoblast adhesion. Acta Biomater. 2011, 8, 449-456. [CrossRef] [PubMed]

83. Zhao, P.; Liu, H.; Deng, H.; Xiao, L.; Qin, C.; Du, Y.; Shi, X. A study of chitosan hydrogel with embedded mesoporous silica nanoparticles loaded by ibuprofen as a dual stimuli-responsive drug release system for surface coating of titanium implants. Colloids Surf. B 2014, 123, 657-663. [CrossRef] 
84. De Giglio, E.; Cometa, S.; Ricci, M.A.; Zizzi, A.; Cafagna, D.; Manzotti, S.; Sabbatini, L.; Mattioli-Belmonte, M. Development and characterization of rhVEGF-loaded poly (HEMA-MOEP) coatings electrosynthesized on titanium to enhance bone mineralization and angiogenesis. Acta Biomater. 2010, 6, 282-290. [CrossRef]

85. Mattioli-Belmonte, M.; Orciani, M.; Ferretti, C.; Orsini, G.; De Giglio, E.; Di Primio, R. Cell behaviour on bioactive polymeric coatings. Ital. J. Anat. Embryol. 2010, 115, 127-133.

86. De Giglio, E.; Sabbatini, L.; Zambonin, P.G. Development and analytical characterization of cysteine-grafted polypyrrole films electrosynthesized on Ptand Ti-substrates as precursors of bioactive interfaces. J. Biomater. Sci. Polym. Ed. 1999, 10, 845-858. [CrossRef]

87. De Giglio, E.; Sabbatini, L.; Colucci, S.; Zambonin, G. Synthesis, analytical characterization and osteoblast adhesion properties on RGD-grafted polypyrrole coatings on titanium substrates. J. Biomater. Sci. Polym. Ed. 2000, 11, 1073-1083. [CrossRef]

88. Buxadera-Palomero, J.; Calvo, C.; Torrent-Camarero, S.; Gil, F.J.; Mas-Moruno, C.; Canal, C.; Rodríguez, D. Biofunctional polyethylene glycol coatings on titanium: An in vitro-based comparison of functionalization methods. Colloids Surf. B 2017, 152, 367-375. [CrossRef] [PubMed]

89. De Giglio, E.; Cometa, S.; Calvano, C.D.; Sabbatini, L.; Zambonin, P.G.; Colucci, S.; Di Benedetto, A.; Colaianni, G. A new titanium biofunctionalized interface based on poly(pyrrole-3-acetic acid) coating: Proliferation of osteoblast-like cells and future perspectives. J. Mater. Sci. Mater. Med. 2007, 18, 1781-1789. [CrossRef] [PubMed]

90. Li, G.; Yang, P.; Huang, N. Layer-by-layer construction of the heparin/fibronectin coatings on titanium surface: stability and functionality. Phys. Procedia 2011, 18, 112-121. [CrossRef]

91. Ye, S.H.; Johnson, C.A., Jr.; Woolley, J.R.; Oh, H.I.; Gamble, L.J.; Ishihara, K.; Wagner, W.R. Surface modification of a titanium alloy with a phospholipid polymer prepared by a plasma-induced grafting technique to improve surface thromboresistance. Colloids Surf. B 2009, 74, 96-102. [CrossRef] [PubMed]

92. Durairaj, R.B.; Ramachandran, S. In vitro characterization of electrodeposited hydroxyapatite coatings on titanium (Ti6AL4V) and magnesium (AZ31) alloys for biomedical application. Int. J. Electrochem. Sci. 2018, 13, 4841-4854. [CrossRef]

93. Vranceanu, D.M.; Tran, T.; Ungureanu, E.; Negoiescu, V.; Tarcolea, M.; Dinu, M.; Vladescu, A.; Zamfir, R.; Timotin, A.C.; Cotrut, C.M. Pulsed electrochemical deposition of Ag doped hydroxyapatite bioactive coatings on Ti6Al4V for medical purposes. Univ. Politeh. Buchar. Sci. Bull. Ser. B Chem. Mater. Sci. 2018, 80, 173-184.

94. Utku, F.S.; Seckin, E.; Goller, G.; Tamerler, C.; Urgen, M. Electrochemically designed interfaces: Hydroxyapatite coated macro-mesoporous titania surfaces. Appl. Surf. Sci. 2015, 350, 62-68. [CrossRef]

95. De Giglio, E.; De Gennaro, L.; Sabbatini, L.; Zambonin, G. Analytical characterization of collagen-and/or hydroxyapatite-modified polypyrrole films electrosynthesized on Ti-substrates for the development of new bioactive surfaces. J. Biomater. Sci. Polym. Ed. 2001, 12, 63-76. [CrossRef]

96. Zhang, S.; Cheng, X.; Shi, J.; Pang, J.; Wang, Z.; Shi, W.; Liu, F.; Ji, B. Electrochemical deposition of calcium phosphate/chitosan/gentamicin on a titanium alloy for bone tissue healing. Int. J. Electrochem. Sci. 2018, 13, 4046-4054. [CrossRef]

97. Avcu, E.; Avcu, Y.Y.; Baştan, F.E.; Rehman, M.A.U.; Üstel, F.; Boccaccini, A.R. Tailoring the surface characteristics of electrophoretically deposited chitosan-based bioactive glass composite coatings on titanium implants via grit blasting. Prog. Org. Coat. 2018, 123, 362-373. [CrossRef]

98. Mokabber, T.; Lu, L.Q.; Van Rijn, P.; Vakis, A.I.; Pei, Y.T. Crystal growth mechanism of calcium phosphate coatings on titanium by electrochemical deposition. Surf. Coat. Technol. 2018, 334, 526-535. [CrossRef]

99. Gristina, A.G.; Naylor, P.; Myrvik, Q. Infections from biomaterials and implants: A race for the surface. Med. Prog. Through Technol. 1988, 14, 205-224.

100. De Giglio, E.; Cometa, S.; Ricci, M.A.; Cafagna, D.; Savino, A.M.; Sabbatini, L.; Orciani, M.; Ceci, E.; Novello, L.; Tantillo, G.M.; et al. Ciprofloxacin-modified electrosynthesized hydrogel coatings to prevent titanium-implant-associated infections. Acta Biomater. 2011, 7, 882-891. [CrossRef]

101. Cometa, S.; Mattioli-Belmonte, M.; Cafagna, D.; Iatta, R.; Ceci, E.; De Giglio, E. Antibiotic-modified hydrogel coatings on titanium dental implants. J. Biol. Regul. Homeost. Agents 2012, 26, 65-71. [PubMed]

102. Raj, R.M.; Priya, P.; Raj, V. Gentamicin-loaded ceramic-biopolymer dual layer coatings on the Ti with improved bioactive and corrosion resistance properties for orthopedic applications. J. Mech. Behav. Biomed. Mater. 2018, 82, 299-309. 
103. Hoyos-Nogués, M.; Buxadera-Palomero, J.; Ginebra, M.P.; Manero, J.M.; Gil, F.J.; Mas-Moruno, C. All-in-one trifunctional strategy: A cell adhesive, bacteriostatic and bactericidal coating for titanium implants. Colloids Surf. B 2018, 169, 30-40. [CrossRef] [PubMed]

104. Vargas-Reus, M.A.; Memarzadeh, K.; Huang, J.; Ren, G.G.; Allaker, R.P. Antimicrobial activity of nanoparticulate metal oxides against peri-implantitis pathogens. Int. J. Antimicrob. Agents 2012, 40, 135-139. [CrossRef]

105. Memarzadeh, K.; Vargas, M.; Huang, J.; Fan, J.; Allaker, R.P. Nano metallic-oxides as antimicrobials for implant coatings. In Key Engineering Materials; Kayali, E.S., Göller, G., Akin, I., Eds.; Trans Tech Publications: Zurich, Switzerland, 2012; Volume 493, pp. 489-494.

106. Sowa-Söhle, E.N.; Schwenke, A.; Wagener, P.; Weiss, A.; Wiegel, H.; Sajti, C.L.; Haverich, A.; Barcikowski, S.; Loos, A. Antimicrobial efficacy, cytotoxicity and ion release of mixed metal ( $\mathrm{Ag}, \mathrm{Cu}, \mathrm{Zn}, \mathrm{Mg})$ nanoparticle polymer composite implant material. BioNanoMaterials 2013, 14, 217-227. [CrossRef]

107. De Giglio, E.; Cafagna, D.; Cometa, S.; Allegretta, A.; Pedico, A.; Giannossa, L.C.; Sabbatini, L.; Mattioli, M.M.; Iatta, R. An innovative, easily fabricated, silver nanoparticle-based titanium implant coating: Development and analytical characterization. Anal. Bioanal. Chem. 2013, 405, 805-816. [CrossRef] [PubMed]

108. Bonifacio, M.A.; Cometa, S.; Dicarlo, M.; Baruzzi, F.; de Candia, S.; Gloria, A.; Giangregorio, M.M.; Mattioli, M.; De Giglio, E. Gallium-modified chitosan/poly (acrylic acid) bilayer coatings for improved titanium implant performances. Carbohydr. Polym. 2017, 166, 348-357. [CrossRef]

109. Cometa, S.; Bonifacio, M.A.; Baruzzi, F.; de Candia, S.; Giangregorio, M.M.; Giannossa, L.C.; Dicarlo, M.; Mattioli, M.; Sabbatini, L.; De Giglio, E. Silver-loaded chitosan coating as an integrated approach to face titanium implant-associated infections: analytical characterization and biological activity. Anal. Bioanal. Chem. 2017, 409, 7211-7221. [CrossRef]

110. Bonifacio, M.A.; Cometa, S.; De Giglio, E. Simulating bacteria-materials interactions via agent-based modeling. In Italian Workshop on Artificial Life and Evolutionary Computation; Rossi, F., Mavelli, F., Eds.; Springer: Berlin, Germany, 2015; pp. 77-82.

111. GhavamiNejad, A.; Aguilar, L.E.; Ambade, R.B.; Lee, S.H.; Park, C.H.; Kim, C.S. Immobilization of silver nanoparticles on electropolymerized polydopamine films for metal implant applications. Colloids Interface Sci. Commun. 2015, 6, 5-8. [CrossRef]

112. Eraković, S.; Janković, A.; Matić, I.Z.; Juranić, Z.D.; Vukašinović-Sekulić, M.; Stevanović, T.; Mišković-Stanković, V. Investigation of silver impact on hydroxyapatite/lignin coatings electrodeposited on titanium. Mater. Chem. Phys. 2013, 142, 521-530. [CrossRef] 